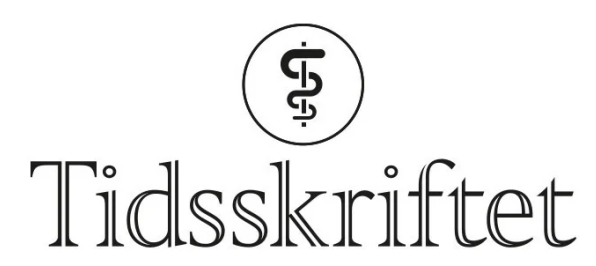

DEN NORSKE LEGEFORENING

\title{
Avvent oftest prøvesvar før oppstart av antibiotikabehandling
}

KOMMENTAR

\section{RUTH EIG}

r.d.ig@medisin.uio.no

Ruth Eig er lege og rådgiver, Antibiotikasenteret for Primærmedisin, Universitetet i Oslo.

\section{SIGURD HØYE}

Ingen av forfatterne har oppgitt noen interessekonflikter.

Vi takker Hartgill, Nodenes og Moi for en god oppsummering av kunnskapsgrunnlaget omkring indikasjon for testing og behandling av genital mykoplasmainfeksjon (1) . Resistensutvikling er dessverre en svært relevant problemstilling i behandlingen av flere infeksjonssykdommer, og genital mykoplasmainfeksjon er et godt eksempel. Artikkelens innhold er i hovedsak i tråd med anbefalingene i Nasjonal faglig retningslinje for antibiotikabruk i primærhelsetjenesten, som nå foreligger i revidert utgave og er ute på åpen høring (므).

Ved påvist uretritt eller cervisitt anbefaler Hartgill og medforfattere antibiotikabehandling uten å vente på prøvesvar. Det er imidlertid ikke alltid like enkelt å stille diagnosen uretritt eller cervisitt sikkert på allmennpraktikerens kontor, hvor bruken av mikroskop i diagnostikken nå er lite utbredt. Derfor anbefaler retningslinjen at kun menn med akutte plager som dysuri og utflod fra uretra, eller kvinner med symptomer og funn som gir mistanke om akutt bekkeninfeksjon, bør tilbys behandling før prøvesvar foreligger. Mange pasienter kommer med et mer diffust symptombilde uten tydelige funn eller sterke plager. I slike tilfeller bør man avvente prøvesvar for å unngå unødig bruk av antibiotika. Dette gjelder også for oppfølging av partner; kun behandling ved positivt prøvesvar.

Vi vil oppfordre klinikere til å følge de oppdaterte retningslinjene og hvis mulig avvente oppstart av behandling inntil prøvesvar foreligger. En slik strategi vil redusere risikoen for unødvendig antibiotikabehandling og resistensutvikling, uten å gå på bekostning av pasientens utsikt til bedring.

\section{LITTERATUR}

1. Hartgill U, Nodenes K, Moi H. På vei mot en multiresistent seksuelt overførbar infeksjon? Tidsskr Nor Legeforen 2021; 141. doi: 10.4045/tidsskr.21.0441. [PubMed][CrossRef] 
2. Helsedirektoratet. Antibiotika i primærhelsetjenesten (høringsutkast).

https://www.helsedirektoratet.no/retningslinjer/antibiotika-i-primaerhelsetjenesten-horingsutkast Lest 7.9.2021.

Publisert: 27. september 2021. Tidsskr Nor Legeforen. DOI: 10.4045/tidsskr.21.0625

(C) Tidsskrift for Den norske legeforening 2023. Lastet ned fra tidsskriftet.no 26. april 2023. 